\title{
Recent Advances in the Application, Design, and Operations \& Maintenance of Aerated Treatment Wetlands
}

\author{
Jaime Nivala ${ }^{1, * \mathbb{D}}$, Clodagh Murphy ${ }^{2}$ and Andrew Freeman ${ }^{2}$ \\ 1 National Research Institute for Agriculture, Food, and Environment (INRAE), UR REVERSAAL, \\ 5 rue de la Doua, CS20244, 69625 Villeurbanne CEDEX, France \\ 2 ARM Group Limited, Rydal House, Colton Road, Rugeley, Staffordshire WS15 3HF, UK; \\ clodagh.murphy@armgroupltd.co.uk (C.M.); andy.freeman@armgroupltd.co.uk (A.F.) \\ * Correspondence: jaime.nivala@gmail.com
}

Received: 27 March 2020; Accepted: 17 April 2020; Published: 21 April 2020

\begin{abstract}
This paper outlines recent advances in the design, application, and operations and maintenance $(\mathrm{O} \& \mathrm{M})$ of aerated treatment wetland systems as well as current research trends. We provide the first-ever comprehensive estimate of the number and geographical distribution of aerated treatment wetlands worldwide and review new developments in aerated wetland design and application. This paper also presents and discusses first-hand experiences and challenges with the O\&M of full-scale aerated treatment wetland systems, which is an important aspect that is currently not well reported in the literature. Knowledge gaps and suggestions for future research on aerated treatment wetlands are provided.
\end{abstract}

Keywords: aeration; constructed wetland; horizontal flow; wastewater; vertical flow

\section{Introduction}

Aerated wetlands are saturated constructed wetland treatment systems that have an integrated aeration system. The technology was originally developed and patented in the United States [1], having the trade mark of Forced Bed Aeration (FBA ${ }^{\mathrm{TM}}$ ). The addition of artificial aeration provides air bubbles that ascend through the saturated water column of the wetland. During bubble ascent, oxygen is transferred from the gaseous to dissolved state, thereby increasing oxygen transfer rate (OTR) into the water being treated, well beyond OTRs that can be achieved in passive constructed wetland configurations. Consequently, aerated treatment wetlands are capable of increased pollutant removal rates compared to conventional non-aerated treatment wetlands [2]. Aerated wetlands offer a high treatment efficacy and final effluent quality for removal of variety of aerobically degradable pollutants in a small system footprint. These characteristics have resulted in the implementation of aerated wetlands globally, for a wide range of treatment applications and today, there are aerated wetlands operating in North America, South America, Europe, Africa, and Asia. Aerated wetland technology has been available for over twenty years; however, implementation has increased dramatically over the past ten years, affording key insights into operational challenges associated with these intensified treatment wetland systems and also, highlighting design modifications that could optimise treatment capacity, energy efficiency and operation and maintenance $(\mathrm{O} \& M)$ requirements.

\section{Global Application}

Input from the international treatment wetland community reveals that there are currently nearly 500 aerated wetland systems operating worldwide (Figure 1). The countries with the most aerated 
wetlands are the USA, followed by Denmark and the United Kingdom (UK). Application of aerated treatment wetlands in European countries is steadily increasing (mainly for treatment of domestic wastewater), and first pilot-scale or full-scale systems have been constructed in Africa, Asia and South America.

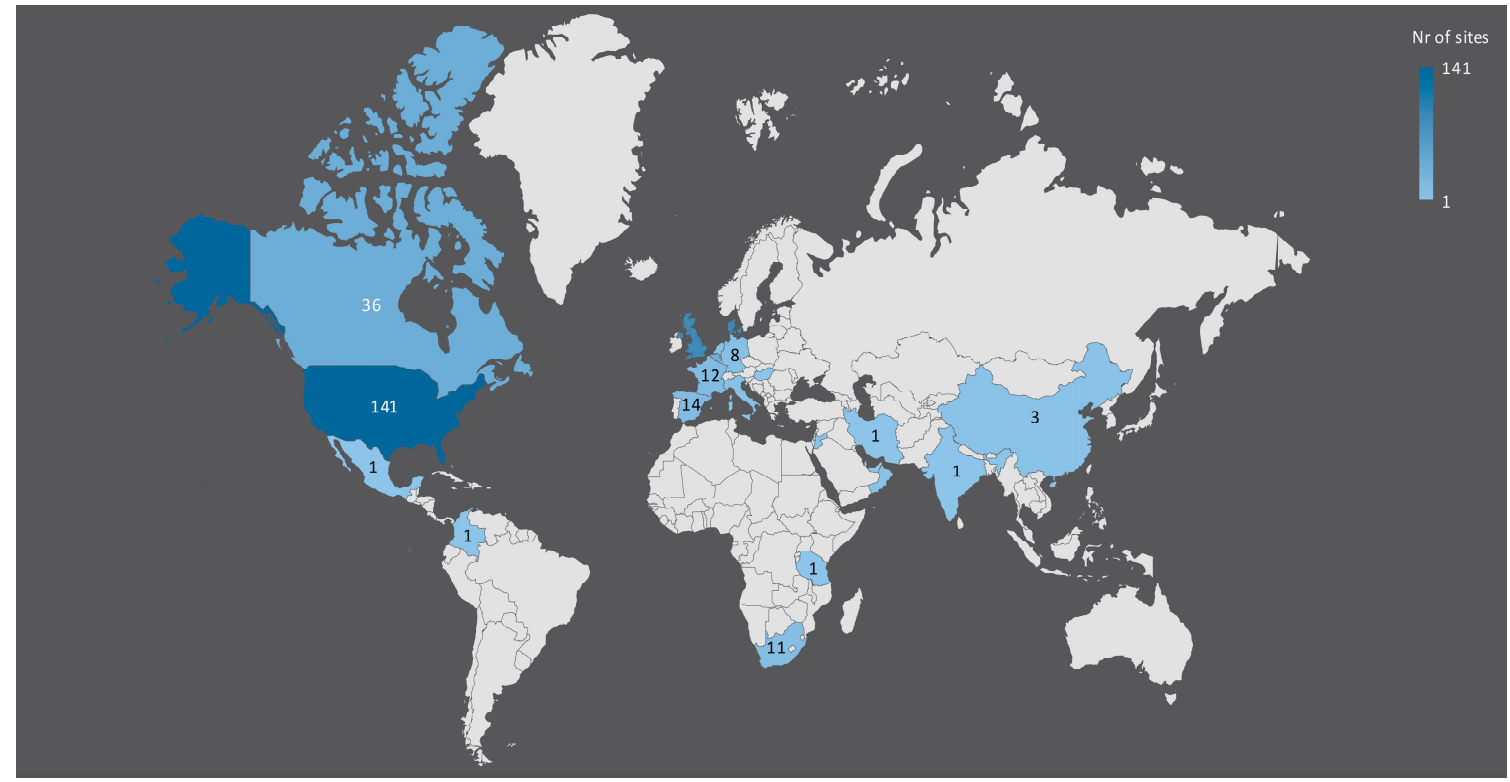

Figure 1. Worldwide distribution of aerated treatment wetland systems as of June 2019.

Subsurface flow aerated wetlands are often used for treating high-strength, highly variable or complex industrial effluents such as landfill leachate $[3,4]$, groundwater contaminated with hydrocarbons [5], food processing wastewater [6,7], mine tailings [8,9], residual dye wastewater [10,11], swine wastewater treatment [12] and de-icer contaminated airport run-off [13-15]. Subsurface flow aerated wetlands have been successfully demonstrated in cold climates, where the use of an insulation layer prevents the wetland water from freezing [16], despite air temperatures below $-25^{\circ} \mathrm{C}$ and wetland water temperatures as low as $0.1^{\circ} \mathrm{C}$ [17].

The use of aerated wetlands for the treatment of domestic and municipal wastewater (collectively referred to as "sewage") has significantly increased in the last ten years, with many systems being built outside of North America. In the UK, almost 50\% of the total number of full-scale operational aerated wetland systems have been retrofitted into existing, formerly passive wetlands as part of a refurbishment program. Wetlands that have become clogged or are no longer providing sufficient treatment to achieve tighter water quality standards, are refurbished by removing, washing and replacing the gravel media [18]. The aeration system is retrofitted into the existing infrastructure prior to replacing the media rather than demolish and reconstruct the treatment wetland. Retrofitting aeration into an existing passive constructed wetland has proven popular in order to significantly increase treatment capacity within the same footprint, whilst utilising existing assets to minimise capital expenditure and to extend the asset lifetime [19-21]. Figure 2 shows the distribution of aerated treatment wetlands by country and treatment application. Sewage is the predominant type of wastewater treated (91\%), followed by industrial (6\%), agricultural (2\%) and event-driven flows (combined sewer overflow \& surface water runoff) (1\%). 


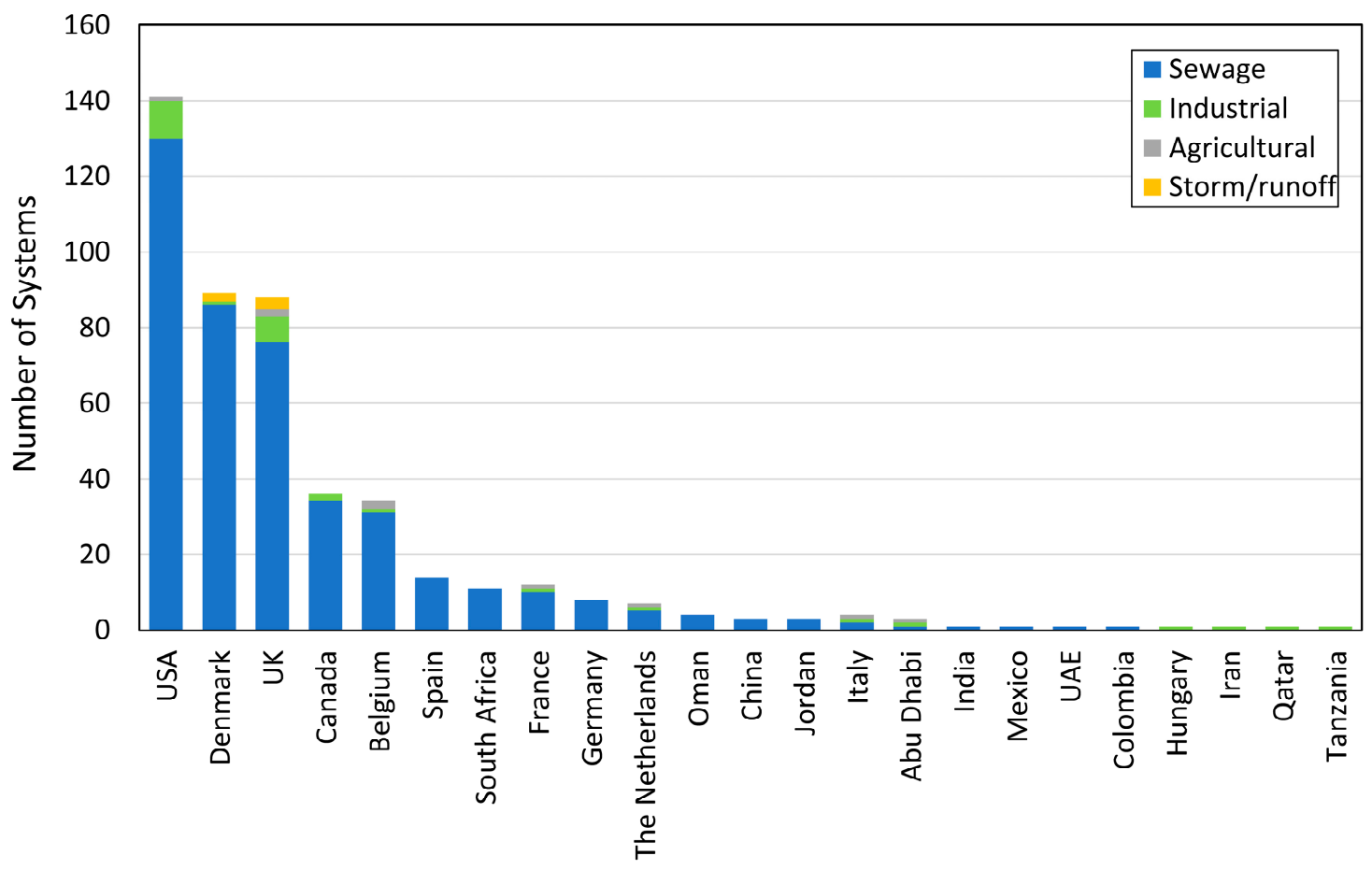

Figure 2. Types of wastewater treated by aerated treatment wetland systems as of June 2019.

The inherently variable nature of weather-based events provides a unique challenge to wetland design. Unlike "steady-state" treatment systems, where the hydraulic and organic load is relatively consistent, event-driven systems must be designed to handle short-term, but often significant organic loads associated with 'first flush' of stormwater and potentially long periods of drought whereby flows and pollutant concentrations are negligible. Examples of event-driven aerated wetland systems include the treatment of winter stormwater run-off contaminated with de-icing fluids from airports $[13,14]$ and Combined Sewer Overflows (CSO) [21,22]. One of the advantages of aeration in this context is that the aeration system can be used intermittently, or airflow can be 'ramped up', in response to short-term variations in biochemical oxygen demand (BOD) and nitrification demands associated with weather-based events. Customisable aeration minimises power consumption whilst allowing operational control of the aerobic conditions within the wetland bed.

\section{Design Considerations}

The design of the aerated wetland aeration system requires an accurate calculation of the expected oxygen demand $\left(\mathrm{kg} \mathrm{O}_{2} / \mathrm{d}\right)$ of the wastewater requiring treatment, to enable correct sizing of the aeration system. The oxygen demand of the wastewater can be calculated via standard wastewater design practices [23]. In order to accurately determine the required airflow from the calculated oxygen demands, an understanding of the Oxygen Transfer Efficiency (OTE) is required, defined as the percent of $\mathrm{O}_{2}$ injected into the system in the gaseous air state, that can be transferred into the dissolved state under given conditions of temperature, barometric pressure, airflow rates and dissolved oxygen concentrations [24]. The OTE of aeration systems can be determined empirically following Standard Oxygen Transfer Efficiency (SOTE) testing procedures outlined in the American Society of Civil Engineers (ASCE) standard, ASCE/EWRI 2-06 'Measurement of Oxygen Transfer in Clean Water' [24] to establish a SOTE expressed as percent per meter depth $(\% / \mathrm{m})$ for a given aeration system. These tests are performed under very controlled conditions using potable water. The Actual Standard Oxygen Transfer Efficiency (aSOTE) of the aeration system will ultimately depend on many factors, including wastewater composition, presence of surfactants, wastewater temperature, operational pressures, the depth of the saturated media, the physical design and layout of the aeration system, 
type of diffusers selected and blower operating efficiency. The aeration system should be designed to distribute airflow evenly across the bottom surface of the bed; simplified designs involving holes drilled in Polyvinyl Chloride (PVC) or Unplasticised Polyvinyl Chloride (UPVC) pipes will not achieve this effectively, resulting in a suboptimal aSOTE. The use of HDPE drip irrigation tubing with emitters has been reported in the literature $[25,26]$; however, the specific design details of the aeration system have yet to be published in detail. Uniform air distribution in aerated wetlands can be hindered by the use of pre-fabricated air diffusors or by the use of sand as the main media [27]. Medium to coarse gravel is used as the main media in aerated treatment wetlands, because the pore space is large enough to allow the passage of air bubbles under low airflow rates. Empirical testing can be used to define the aSOTE and to ensure uniform distribution of air flow and suitability of a specific method for air diffusion into the wetland bed [25]. The optimal aerated wetland aeration system design strikes a balance between the residence time of the bubble (i.e., the saturated media depth through which the air bubble has to ascend), the bubble diameter, and the aeration efficiency (i.e., the amount of $\mathrm{O}_{2}$ transferred per unit of energy input, expressed in $\mathrm{kg} \mathrm{O}_{2} \mathrm{kWh}$ ) [28].

In cold climate applications, the thermal design of the wetland system is of great importance. The use of an insulating cover layer can reduce heat loss to the atmosphere in wintertime, keeping wetland water temperatures above zero despite air temperatures as low as $-30{ }^{\circ} \mathrm{C}[16,17]$. The use of snow for insulation purposes is not recommended because it does not provide reliable insulation during periods of little or no snow. In subsurface flow aerated wetlands in Minnesota, USA, a $15 \mathrm{~cm}$ layer of mulch and a $5 \mathrm{~cm}$ air gap under the mulch has proven to be sufficient, but the mulch must be well-decomposed so as not to exert a secondary organic load to the system, have a balanced nutrient composition and circumneutral $\mathrm{pH}$, and have a fluffy structure with high fibre content [16]. Mulch that does not meet these requirements can cause problems such as decreased treatment performance, poor plant establishment, or clogging due to wash-out of fine particles.

The first design standard on the design of Horizontal Flow (HF) and Vertical Flow (VF) aerated wetlands was published in Germany in 2017 [29,30] and includes specific recommendations for the specific surface area $\left(\geq 1 \mathrm{~m}^{2}\right.$ surface area per person equivalent), volumetric COD loading rate $(\leq 100 \mathrm{~g}$ COD per $\mathrm{m}^{3}$ filter body per day), and for aerated HF wetlands a maximum cross-sectional organic loading rate ( $\leq 200 \mathrm{~g}$ COD per $\mathrm{m}^{2}$ cross-sectional area per day). The limits on cross-sectional organic loading were influenced by prior recommendations of $\leq 250 \mathrm{~g} \mathrm{BOD} / \mathrm{m}^{2} \cdot \mathrm{d}$ on the surface area receiving wastewater [31] but most sustainable designs operate at $\leq 100 \mathrm{~g} \mathrm{BOD} / \mathrm{m}^{2} \cdot \mathrm{d}$ [32]. There has been a movement towards the use of COD loading rates (as opposed to BOD loading rates) due to the ease of analysis and quick turnaround time for measuring COD in the laboratory.

Aerated wetlands are effectively attached-growth biological reactors, because the gravel media supports the microbial communities responsible for pollutant degradation. In addition to microbial oxygen and carbon requirements, biomass also has a nutrient and micronutrient demand [33]. Nutrient-limited systems can display operational issues including microbial stress responses, most notably foaming or production of polysaccharide slime formations [34,35] (Figure 3) that can reduce pollutant removal efficacy and ultimately reduce the hydraulic conductivity, causing media clogging. Careful design including nutrient dosing of a liquid fertilizer is required to overcome operational issues in nutrient-limited wastewater treatment applications. 


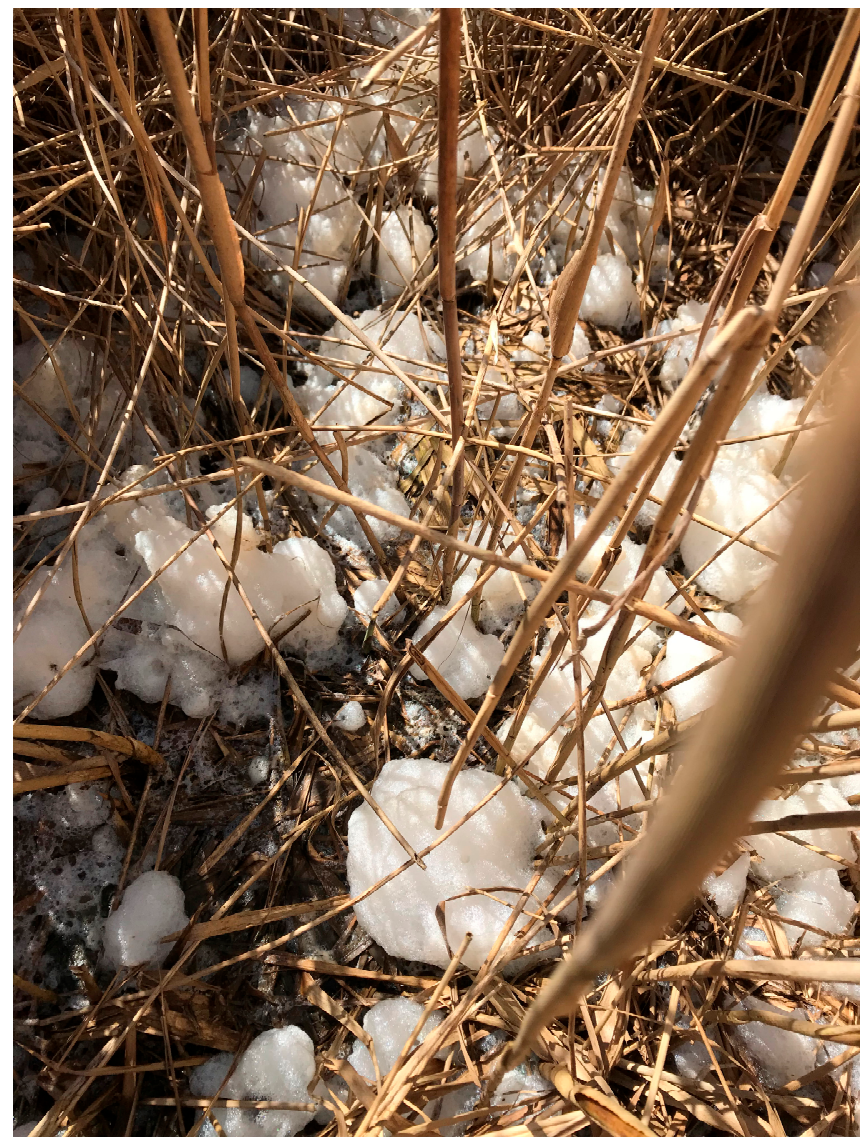

Figure 3. Microbial stress response in a nutrient-limited wetland, producing a characteristic foam.

Variations of aerated wetland technology are continuously being developed and tested. A two-stage wetland system consisting of first-stage French VF wetlands followed by an aerated HF wetland cell is being piloted in Jordan [36], and a similar type of system, but portable, has also been constructed in Oman [37]. Aeration has also been recently applied to floating treatment wetland technology, providing potential advantages for operation and maintenance (easy access to diffusers, possibility for sludge removal) and cost savings (since gravel is not needed) [38]. Patents have been filed for variations of single-stage wetlands that receive raw wastewater on the filter surface and have a saturated, aerated gravel bed underneath, thus providing sludge/solids treatment and wastewater treatment in one step, one of which was just recently granted [39]. The Rhizosph'air ${ }^{\circledR}$ is being tested at column-scale $\left(0.1 \mathrm{~m}^{2}\right)$, pilot-scale $\left(20 \mathrm{~m}^{2}\right)$ and full-scale $\left(1400 \mathrm{~m}^{2}\right)$ [40] as well as another variation, Oxyphyltre ${ }^{\circledR}$, at bench-scale $\left(1 \mathrm{~m}^{2}\right)$ [41]. An aerated wetland patent has been granted in Iran for a new aerated wetland design that promotes aerobic precipitation and co-precipitation of metals from oil refinery wastewater [42]. The use of alternative media, such as ceramsite, in constructed wetlands with "micro-aeration" in the front of the bed has shown to be promising for removal of Total Phosphorus (TP), Orthophosphate $\left(\mathrm{PO}_{4}-\mathrm{P}\right)$ and ammonium $\left(\mathrm{NH}_{4}-\mathrm{N}\right)$ [43]. The use of a novel aeration approach in a Free Water Surface (FWS) treatment wetland has also been recently reported, where a pure oxygen contactor is used to supersaturate water with dissolved oxygen (DO) in order to achieve sustained, near-complete nitrification despite near-freezing water temperatures [44].

\section{Research Trends}

Much of the original research and development on aerated wetlands originated from the efforts of and funding from private companies, with first results presented only in national or international conference proceedings [6,45-47]. The first bench-scale research on the topic was published by 
Lockhart [48] and the first peer-reviewed journal article on full-scale aerated wetland application was published by Wallace and Kadlec [5]. The earliest full-scale and outdoor pilot-scale aerated treatment wetland systems received continuous $(24 \mathrm{~h} / \mathrm{d})$ aeration [3,19,20,26,49-51]. Many bench-scale and pilot-scale research studies have investigated the use of intermittent aeration [51-65]. Intermittent aeration via windmill-powered air pumps has also been tested [66]. By far, most research studies on aerated wetlands are bench-scale studies operated under controlled steady-state conditions, run for relatively short periods of time (less than one year). More studies on outdoor pilot-scale systems and on full-scale systems are needed in order to better understand the dynamics of pollutant removal in aerated treatment wetland systems [67].

In terms of pollutant removal, intermittent aeration generally increases removal of Total Nitrogen (TN) in aerated wetlands creating aerobic and anaerobic zones to facilitate nitrification and denitrification simultaneously, whilst also reducing the overall energy demand of the treatment system. Aeration can both increase microbial growth and reduce volatile suspended solids accumulation in treatment wetlands [68]. Aeration acts against gravitational settling and inadvertently promotes suspension of solids in the water column. Anecdotal observations of annual spikes in effluent TSS concentrations in mature ( $>5$ years old) HF and VF aerated wetlands have been observed in autumn [69]; however, the reasons for this are not known. The removal of TP has been reported to be higher in aerated wetlands than in non-aerated wetlands in a number of studies, with Oxidation Reduction Potential (ORP) cited as an important factor [70]. The removal of E. coli in aerated wetlands has been reported a few times in the literature, but only for short-term datasets on the order of one year [71,72]. HF aerated wetlands are capable of approximately four log unit removal of $E$. coli whereas VF aerated wetlands are capable of approximately only two log unit removal. The difference in hydraulic behaviour between HF aerated wetlands and VF aerated wetlands is significant, with tracer-tested HF aerated wetlands functioning hydraulically as 4.5 tanks-in-series (TIS) and VF aerated wetlands functioning as 1.1 TIS (e.g., hydraulics described as almost completely well-mixed) [73]. The observed differences in hydraulic functioning of HF and VF aerated wetlands are confirmed by both internal water quality profiles [71,73] and microbial community metabolic profiling [74]. HF aerated wetlands for secondary treatment of domestic wastewater are capable of approximately four log unit removal of E. coli [71]. Stefanakis et al. [75] studied the use of an aerated wetland for tertiary treatment, reporting final effluent concentrations for E. coli, Fecal Coliform, and Intestinal Enterococci of 41, 14, and 3 CFU/100 mL, which are all below the WHO guidelines for reuse of treated water in agriculture [76].

Different arrangements of the spatial positioning of the aeration in aerated wetlands are also reported in the literature [77-81]. For example, Freeman et al. [82] report the use of a phased aeration configuration, developed from tapered aeration designs in the activated sludge process, whereby the airflow is provided across the base of an HF wetland bed in proportion to the estimated oxygen demand of the wastewater that decreases from the inlet to the outlet. This approach aims to avoid under-aeration of the inlet zone (where the highest wastewater oxygen demand occurs) and over-aeration near the outlet zone (where the oxygen demand is at its lowest) and performed more efficiently than uniform aeration for removal of $\mathrm{COD}, \mathrm{BOD}_{5}$, and TSS from airport stormwater runoff containing de-icing fluid.

Because aerated wetlands rely on the use of air blowers, a question arises as to what happens to the performance of the system during and after maintenance periods, blower failures or power outages. The first study to provide insight into this question was conducted on a $10 \mathrm{~m}^{2} \mathrm{VF}$ aerated wetland in the UK [83]. The wetland system was subject to periods of two weeks with no aeration. Dissolved oxygen concentrations dropped to near zero within $12 \mathrm{~h}$ of switching off the aeration. Nitrification effectively ceased within $48 \mathrm{~h}$ after the aeration was switched off and resumed within $48 \mathrm{~h}$ of turning the aeration back on after the two-week pause. Recovery of nitrification was observed on the order of days, which is much shorter than that observed in start-up of new aerated wetland systems, where establishment of nitrifying bacteria resulting in stable nitrification can take on the order of weeks to months depending on temperature. A follow-up study on an aerated HF wetland and an aerated VF wetland in Germany took a deeper look into the resilience of aerated wetlands in terms of carbon and 
nitrogen removal [84]. Both HF and VF aerated wetlands were able to fully recover after simulation of air pump failure in both summer and winter conditions (water temperatures of $>18{ }^{\circ} \mathrm{C}$ and $<10{ }^{\circ} \mathrm{C}$, respectively). Slower recovery times for the HF aerated wetland were attributed to the lower degree of hydraulic mixing compared to that in the VF aerated wetland, which functions as a completely-mixed reactor [59]. Based on case studies reported in the literature, aerated wetlands are relatively resilient to disruptions of air supply on the order of one to two weeks. In most cases, a remote alarm signal sent to the operator that a power outage has occurred and the site needs to be checked should be sufficient. In remote locations or situations where a decrease in treatment efficacy cannot be tolerated, a back-up power supply could prove to be useful.

The application of process-based models to aerated wetland systems aims to provide new insights for improving design and operation. A reactive transport model for HF aerated wetlands has been recently developed and validated on an outdoor pilot-scale system, where hydraulic behaviour and removal of $\mathrm{COD}, \mathrm{NH}_{4}-\mathrm{N}$, and $\mathrm{NO}_{x}-\mathrm{N}$ were reliably simulated [85]. The model was further developed to predict treatment performance and dynamic response of $\mathrm{DO}, \mathrm{COD}, \mathrm{NH}_{4}-\mathrm{N}$, and $\mathrm{NOx}-\mathrm{N}$ concentrations in pore water and final effluent before, during and after a period of aeration interruption [86]. Removal processes and bacterial dynamics in saturated up-flow VF aerated wetlands have also recently been modelled using the HYDRUS Wetland Module coupled with the CWM1 biokinetic model [87]. To better understand the link between oxygen mass transfer and the organic carbon concentration of the wastewater, lab-scale column studies using clean water and wastewater demonstrated that the pollutant content of the water can reduce oxygen transfer in HF aerated wetland systems, and computer simulations showed that the decreased oxygen transfer can be linked to a loss in treatment efficacy [88].

Although treatment wetland systems, including aerated treatment wetlands, are not specifically designed for the removal of micropollutants, removal of these compounds does occur. Research on micropollutant removal in conventional (non-aerated) HF treatment wetlands started in the 2000s [89], whereas the first study on micropollutant removal in an aerated wetland was conducted nearly ten years later [90]. A recent review on the role of design and operational factors in the removal of pharmaceutical compounds in treatment wetlands identifies aerobic biodegradation as a predominant removal mechanisms for a range of pharmaceutical compounds [91]. Studies on outdoor pilot and full-scale wetland systems treating real wastewater generally show that aerated wetlands exhibit higher micropollutant removal efficacy than conventional (non-aerated) wetland types [92].

Kahl et al. [93] report removal of seven indicator micropollutants in six treatment wetland systems, including two aerated wetlands. Their study showed that aerated treatment wetlands (both HF and VF) showed higher micropollutant removal than a (non-aerated) HF wetland. Auvinen et al. [94] report that continuous $(24 \mathrm{~h} / \mathrm{d})$ aeration improved removal of a variety of micropollutants from municipal wastewater as well as hospital wastewater. Nivala et al. [69] report that DO, ORP, water temperature and design complexity are the most important factors determining removal of selected micropollutants, and that aerated wetlands exhibit more robust removal of micropollutants (e.g., smaller variations in percent mass removal over the course of a year) compared to other wetland designs. In another study, aeration has been shown to improve removal of ibuprofen in planted and unplanted wetland mesocosms treating synthetic wastewater [95]. The first application of in vitro bioassays to treatment wetlands found that aerated wetlands were able to remove biological activity to a greater extent than a conventional municipal treatment plant [96].

Aerated treatment wetland technology was originally developed and tested in the United States, in temperate and cold climates. As such, there is a lack of data available on aerated wetlands operating in arid or tropical climates. Current research and development efforts are aiming to fill in this knowledge gap. Strict discharge regulations for Total Nitrogen (TN) and E. coli in Jordan, for example, have been identified as constraints for unsaturated (non-aerated) VF wetlands [97]. Aerated wetlands potentially offer increased removal of TN and E. coli compared to non-aerated VF wetlands. HF aerated wetlands are being piloted for secondary and tertiary treatment of municipal wastewater at a research and demonstration site in Fuheis, Jordan [36]. Two full-scale aerated wetlands have been installed near 
Amman; one to treat the wastewater from a school, and another to treat the wastewater from a "family home" (35 person equivalents). Aerated wetlands are also currently operating in other arid climate countries, including Oman, Abu Dhabi, Iran, Qatar, Tanzania, and the United Arab Emirates (Figure 2).

\section{Operations and Maintenance}

The operations and maintenance of aerated wetlands when compared to conventional HF and VF passive treatment wetlands is more complex from a technical point of view. Typically, treatment wetlands require low maintenance to ensure optimal performance and extend asset life. Maintenance of all wetland systems includes tasks such as periodic weeding, clearance of distribution pipes, management of surface sludge, monitoring clogging and treatment performance. Aerated wetlands have the addition of air blowers and aeration pipework to include in the maintenance schedule.

By their very definition, aerated wetlands require some form of mechanism (typically a mechanical air blower) to deliver oxygen into the wetland via a network of pipes, positioned at the base of the wetland, beneath a granular media such as gravel. The increased engineering and energy consumption associated with the operation of the blowers increases operational expenditure (OPEX) when compared to conventional passive HF and VF constructed wetlands [98,99]. The increase in OPEX is however largely offset by the benefits that aerated wetlands provide compared to passive (non-aerated) wetland systems such as improved efficacy, potential to treat high strength wastewaters, enhanced final effluent quality and improved resilience to shock loads. From a capital expenditure (CAPEX) perspective, the required surface area per PE for aerated wetlands for secondary treatment of wastewater is much less than of non-aerated wetlands: $1 \mathrm{~m}^{2} / \mathrm{PE}$ for aerated wetlands [29] compared to $5 \mathrm{~m}^{2} / \mathrm{PE} \mathrm{for} \mathrm{HF}$ wetlands [100] and $4 \mathrm{~m}^{2} / \mathrm{PE}$ for VF wetlands [29]. Therefore, the overall footprint of an aerated wetland and its associated CAPEX for construction can be lower than that of a passive (non-aerated) wetland system designed to treat an equivalent organic load, due to reduced excavation requirements, liner areas, media fill volumes and collection and distribution pipework lengths. Aerated wetlands also have an additional CAPEX requirement over passive constructed wetlands relating to mechanical blowers, control panels, distribution manifolds and aeration pipework. The increased cost of power consumption of the air pumps has been found to largely be covered by the reduced size of the wetland (compared to a passive, non-aerated wetland design) [101].

Freeman et al. [99] performed a Whole Life Cost (WLC) assessment using total expenditure (TOTEX) to determine the net present value, over a 40-year operational timespan, for aerated wetland technology compared to submerged aerated filters (SAF) and rotating biological contactors (RBC) for treatment applications ranging from 45-1170 population equivalent. The assessment concluded that aerated wetlands were a more economical treatment solution to small community wastewater treatment applications compared with conventional mechanical and electrical technologies such as SAFs and RBCs. Ancillary benefits such as creation of habitat and increased biodiversity provided by aerated treatment wetland systems did not factor into the WLC assessment, but these non-monetary benefits (Ecosystem Services) are becoming increasingly important in choosing sustainable technologies for closing local water cycles, especially in urban environments [102].

\subsection{Air Blowers}

The most commonly used blowers in full-scale aerated wetlands are Fixed Speed Drive (FSD) air blowers, (typically side channel blowers) used on smaller systems to reduce the level of complexity for air delivery control, maintenance and associated TOTEX. The trade-off on cost and control complexity is that FSD blowers are sized to deliver a fixed airflow rate to meet a specified oxygen demand as dictated by the organic loading rate, and generally operate continuously using a duty/standby blower arrangement. Whilst complexity and CAPEX of FSD blowers are generally low, FSD blowers offer limited operational control, risking overaerating the wetland resulting in sub-optimal performance and energy consumption. For example, this is a problem in event-driven systems wherein the oxygen demand is negligible for large periods of time and in sewage treatment applications wherein diurnal 
fluctuations of organic loads, result in low oxygen demands during the night [20]. Selecting the correct size of FSD blower to deliver the required air flow for systems with fluctuating water levels within the wetland can also be problematic. For example, if the water level on the bed is higher than the designed operating level, this exerts a greater blower operating static pressure leading to the pressure relief valve (PRV) activating to release the back pressure and prevent damage to the blower. Unnecessary or over activation of the PRV is not desired as this air is wasted to the atmosphere. Oversizing the blower to deal with occasional higher than design water levels and operating static pressures can lead to sub-optimal and over aeration of the wetland when it is operating at the designed water level.

To combat these operational issues on large sites, that have significant energy requirements and associated OPEX to deliver design airflow rates, variable speed drive (VSD) blowers (typically Positive Displacement or PD blowers) have been more recently utilised to optimise and adjust airflow rates in response to variable organic loads, oxygen demands and increasing operating static pressures due to fluctuating water levels. Blowers with VSDs are operationally more complex than FSD blowers, typically requiring ancillary systems to initiate airflow rate variations in response to wastewater oxygen demand, and therefore have greater associated CAPEX and OPEX because of increased routine operator intervention and maintenance requirements. For example, VSD blowers typically require telemetry connections from online monitoring instruments such as dissolved oxygen (DO) probes, total organic carbon (TOC) monitors, or ammonium $\left(\mathrm{NH}_{4}-\mathrm{N}\right)$ monitors. These water quality instruments relay data at near real time to the VSD, which in turn initiates variations in the blower airflow rate in response to demand, thereby optimising airflow rates and minimizing over aeration when demand is low. These ancillary systems therefore add an additional maintenance requirement and OPEX compared to FSD blowers. Additionally, VSD blowers such as positive displacement (PD) blowers have greater number of mechanical components, require running periodically when not in use and require synthetic oil levels to be routinely topped up to avoid operational issues including seizure of moving parts. Manufacturer guidelines give an anticipated operational expectancy of 20,000-25,000 run hours or three years under normal operating conditions (whichever comes first) before the most typically used FSD side channel blowers and VSD PD blowers require an overhaul (replacement of consumable parts such as bearings or seals). VSD blowers are more energy efficient than FSD as airflow rates can be adjusted according to the wastewater oxygen demand.

\subsection{Air Distribution System}

The provision of sufficient length of airline and number of emitters is essential in ensuring the correct volume of air is delivered into the wetland to meet the oxygen demand. Equal airline and emitter spacing at the bottom of the wetland ensures maximum oxygen transfer capacity within the wetland. Air leaves the emitter as a single bubble, coalescing with other bubbles until buoyancy forces exceed inter pore space pressures and media friction as it rises towards the surface of the wetland. One hypothesis is that the aeration emitter creates a "zone of influence" between the emitter and the water surface (Figure $4 \mathrm{a}$ ), which results in a cone with a diameter of approximately $30 \mathrm{~cm}$ in a one-meter deep wetland cell, but this theory has yet to be scientifically proven. The size of the bubble and the air flow rate has influence on the oxygen transfer rate [28,82]. The smaller the bubble, the greater the surface area for oxygen transfer. As smaller air bubbles coalesce into larger ones, the surface area of the bubble decreases with a resulting decrease in oxygen transfer. The optimization of aeration systems in treatment wetlands is complicated by the presence of granular media. The effect of granular media on SOTE is not fully clear because of the competing effects of bubble coalescence and bubbles that are held in the pore space between the particles of gravel. 
(a) Cone of influence from one aeration emitter

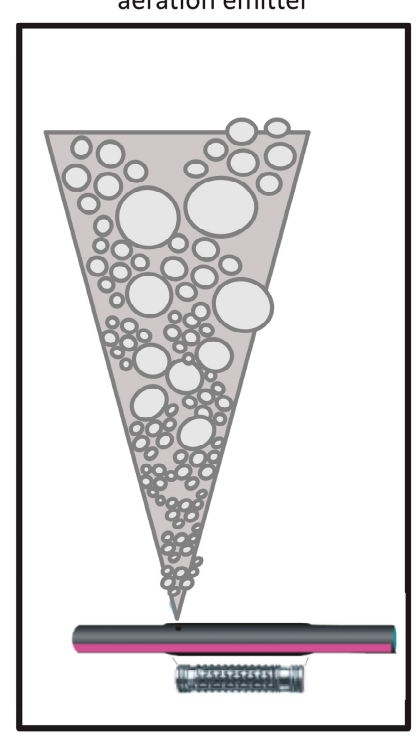

(b) Even distribution of aeration over entire bed

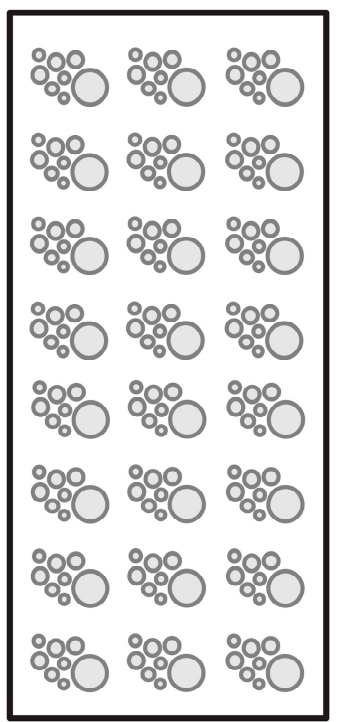

(c) Uneven distribution due to broken connector

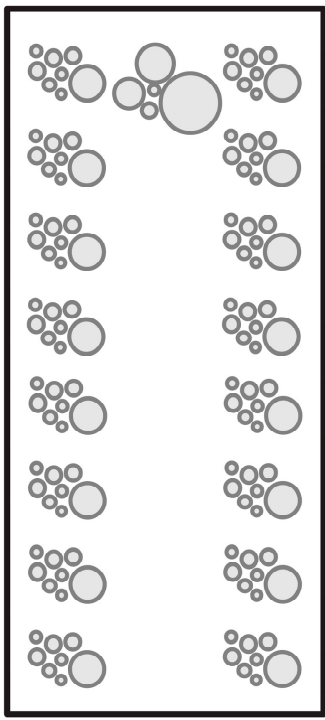

(d) Sporadic distribution due to blocked emitters

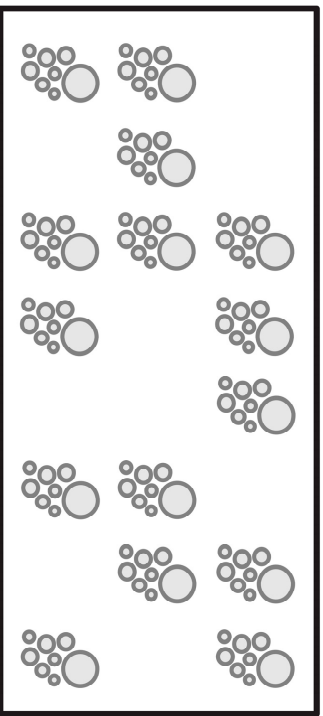

Figure 4. Bubble patterns in aerated treatment wetlands: (a) Visualization of the cone of influence created by one aeration orifice; (b) even bubble distribution across the entire bed; (c) uneven distribution where one connector is broken, allowing excess air to escape through the break in the airline nearest to the aeration manifold; (d) sporadic bubble pattern indicative of blocked emitters.

Wallace et al. [25] found that within one-meter deep bench scale tanks containing no media and gravel media, fine bubble diffusers produced SOTEs of $6.6 \%$ and $4.7 \%$ respectively. In contrast, Collingnon [103] found in a study on an Integrated Fixed-film Activated Sludge (IFAS) system that within a $1.5 \mathrm{~m}$ deep tank, testing of coarse bubble diffusers resulted in an SOTE of $5 \%$ without media and $6.5 \%$ with media. The author hypothesized that the effect of bubble coalescence was negated by bubble hold-up and increased residence time within the media pore space. Butterworth [28] came to a similar conclusion that the presence of a granular media such as gravel forces the bubble to travel a tortuous path through the pore spaces of the gravel, resulting in bubble hold up, thereby extending the residence time of the bubble within the media, allowing for greater oxygen transfer capability than through water alone.

An evenly distributed bubble pattern across the surface of a flooded bed (Figure $4 b$ ) is indicative of an effective aeration system with even air distribution. Changes in the observable bubble pattern from an even distribution to a more sparsely distributed bubble pattern, over time, is a sign that the aeration efficiency is no longer optimal and is indicative of a wider operational issue. The bubble pattern on the flooded surface of the wetland bed gives a clue as to the issue. Turbulent areas with large bubbles emitting from one area is indicative that the airline has become disconnected from the air delivery manifold or that the connectors have come apart (Figure 4c). Sporadic bubble patterns (Figure 4d) with areas with no bubbles is indicative of blocked emitters. This is most likely to occur in industrial effluents through chemical precipitation in the oxygen-rich subsurface environment (Figure 5). Clogging of aeration lines by ferric hydroxide precipitates was reported by an aerated HF wetland treating landfill leachate [3] as well as for a hybrid (VF followed by HF) aerated wetland treating wastewater from a fruit processing industry [104]. Emitter blockages increase the back pressure within the aeration pipework, which can cause the blower to overheat if the pressure relief valve cannot discharge the excess back pressure. 

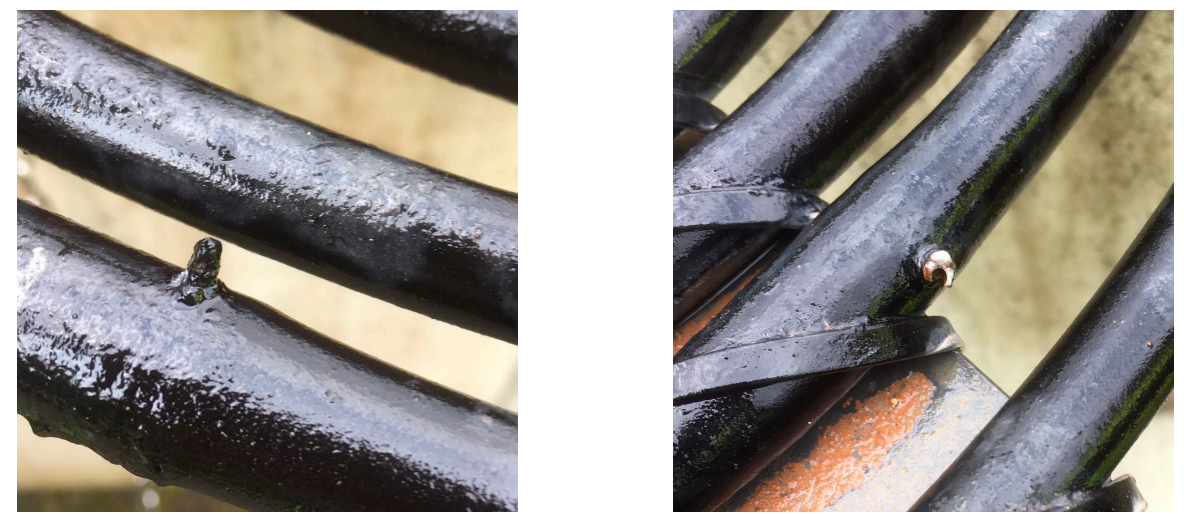

Figure 5. Blocked emitter orifices from an aerated wetland treating landfill leachate.

\subsection{Vegetation}

In Europe and many other parts of the world, Phragmites australis is the predominant plant species used in treatment wetlands. In North America, the use of P. australis is often prohibited, and Phalaris arundinacea, Lythrum salicaria, and Typha latifolia are sometimes viewed as undesirable due to their aggressive growth patterns [105]. In such cases, other species such as Asclepias incarnata, Canna spp., Colocasia esculenta, Cyperus alternifolius, Iris versicolor, Sagittaria latifolia, Scirpus atrovirens, and Scirpus fluviatilis can be used [31].

The addition of aeration to treatment wetlands has had an observable negative effect on the establishment of P. australis. Poor plant establishment was observed at the Langenreichenbach treatment wetland research platform in Germany [106] and at Rugeley, UK (data unpublished). Two horizontal flow wetland cells on the same site in the UK were refurbished in 2011 and retrofitted with aeration (Figure 6). Both wetland cells shared a common influent, with one cell operated with aeration, the other operated without aeration for the purpose of a comparative pollutant removal study [107]. It became apparent that after the first growing season, $P$. australis establishment differed significantly between the aerated and non-aerated wetlands cells. Another study reported that aeration had less of a negative effect on aboveground biomass production of T. latifolia compared to P. australis [107]. The impact of aeration on establishment of $P$. australis was informally discussed at a treatment wetland workshop in Leipzig in June 2013, where similarities at a number of other aerated wetland sites were recognised, particularly in terms of reduced coverage across the bed, initial stunted growth with yellowing leaves (chlorosis) (Figure 7), and altered root growth (Figure 8). It was identified that chlorosis of the leaves was common not only in aerated systems, but also in wetland systems with high redox potential, such as recirculated vertical down flow wetlands.
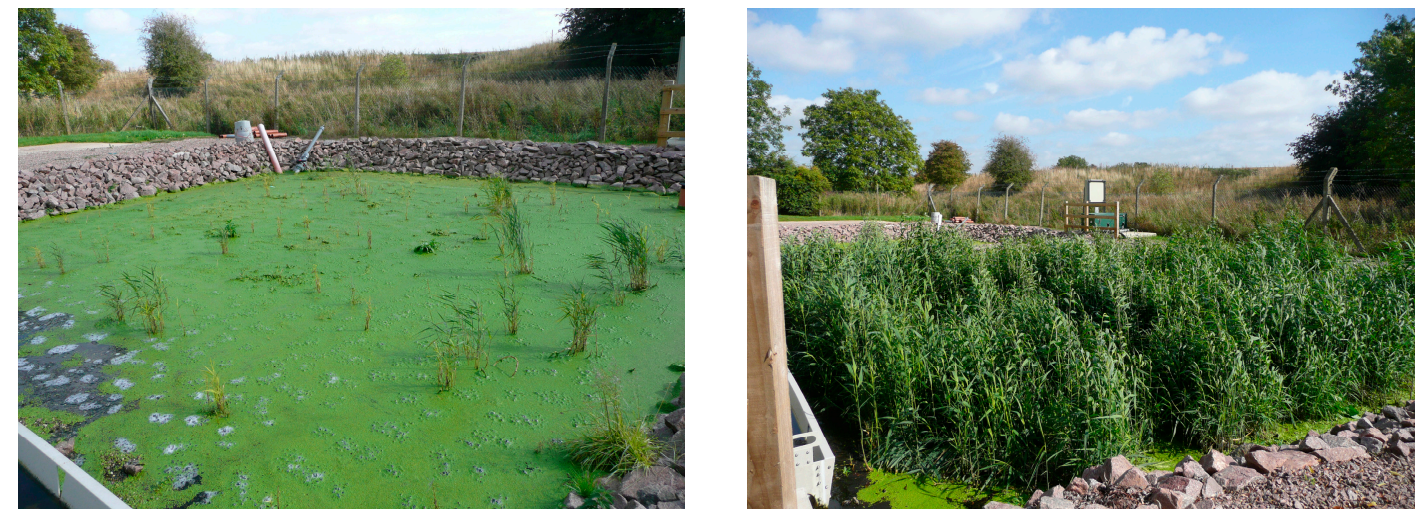

Figure 6. Plant establishment in aerated $(\mathbf{L})$ and non-aerated $(\mathbf{R})$ wetlands receiving a common influent. 


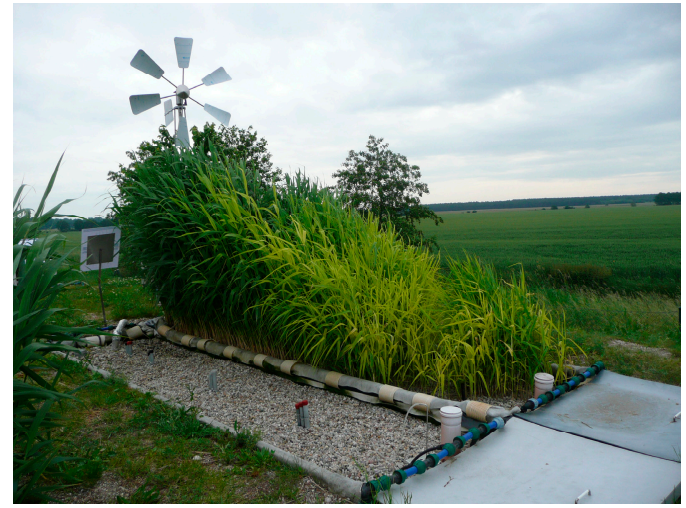

Figure 7. Yellowing and stunted growth of Phragmites australis in an aerated treatment wetland.
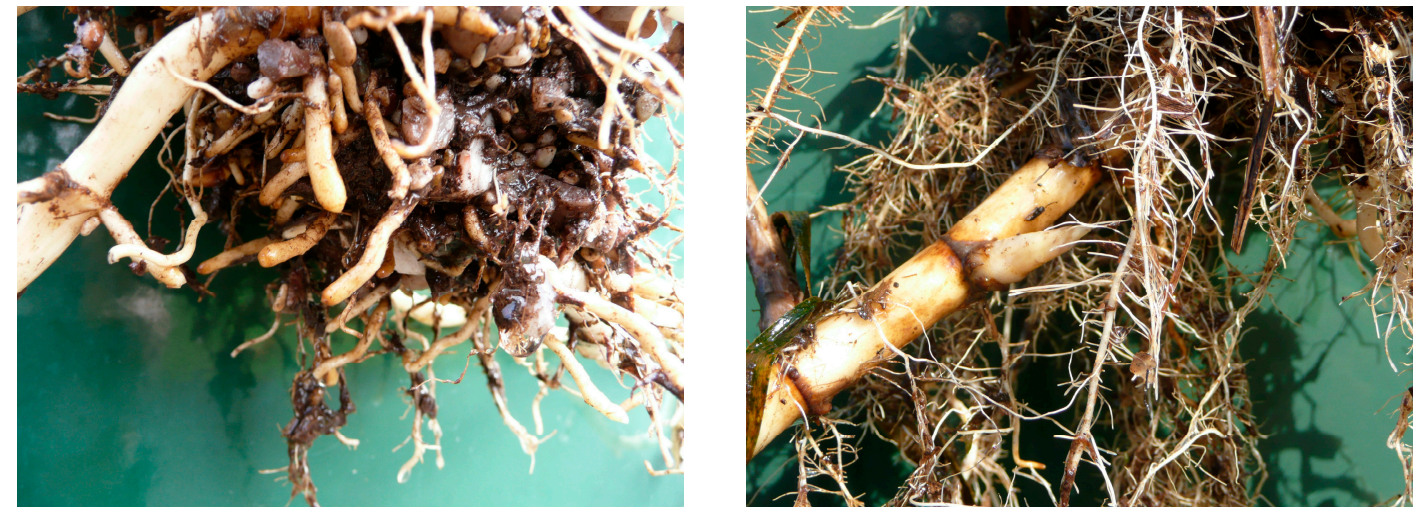

Figure 8. Root balls of Phragmites australis from an aerated wetland (L) and a non-aerated wetland (R) at Rugeley (UK) in 2013.

P. australis grows in conditions with low redox potential in the natural environment. Weedon [108] suggests that low ammonia, high nitrate and high redox potential in the wastewater is believed to result in the iron content taking the non-bioavailable ferric form with insufficient solubility to meet the nutrient demands of the growing plants, resulting directly in insufficient synthesis of chlorophyll (leaf chlorosis) caused by lack of iron. A recent study suggests an iron-rich spray could be used to mitigate leaf chlorosis in P. australis in treatment wetlands [109]. A comparative study of P. australis and T. latifolia in aerated and non-aerated microcosms and full-scale systems by Butterworth et al. [107] identified that the link between macro and micro nutrients and plant growth was inconclusive in providing a mechanism for the observed stunted growth, however that there is a potential for synergistic impact in relation to iron and manganese. It is suggested that the turbulence around the roots from the aeration is not conducive to root growth, creating waxy, stubby roots resulting in stress-induced growth inhibition [107]. The position of the water level relative to the plant stems needs further study for any direct causality. It has been observed on numerous sites during maintenance, that aerated wetlands where the water level is above the surface of the gravel (approximately $50 \mathrm{~mm}$ ) appear to have a negative impact on plant health for $P$. australis compared to aerated wetlands where the water level is at or below the gravel surface level. Water levels above the gravel surface in combination with nitrate-rich effluent and sunlight, due to lack of plant shade, encourages Lemna spp. and algal blooms on the surface of the wetland. Algae such as blanket weed/filamentous or string algae produce fibrous strands, suffocating young plants which further inhibits their growth, and consequently can create odour issues as they decompose if they are not removed. Keeping the water level at or below gravel level will reduce occurrences of algal growth. 
Observations from multiple sites in the UK during routine maintenance, indicate that T. latifolia can tolerate conditions found in aerated wetlands when compared to P. australis. This correlates with the microcosm lab-scale tests conducted over relatively short timescales [107]. However, after several years of growth, T. latifolia has been observed in some systems to produce a dense root mat on the surface of the gravel, which coupled with leaf drop during the winter have resulted in a reduction of the observable bubble pattern and increased back pressure on the blower, causing the pressure relief valve to discharge excessive air volumes, therefore resulting in sub-optimal aeration. This phenomenon has not been observed in aerated systems planted with $P$. australis. The effect of aeration on plant establishment in full-scale systems in North America is not widely reported in the literature. A study by Matthys et al. [45] reported rooting patterns of T. latifolia in aerated, non-aerated and draw-down mesocosms, with the most vertical and lateral root growth observed in the aerated reactor. Further studies on longer-term plant species impacts on aeration systems and static pressures are required.

Plant establishment can be viewed as cosmetic since the treatment performance of aerated wetlands is not compromised by lack of plants [108]. However, a lack of plant coverage from an owner/operator point of view is not ideal. The reduced plant coverage increases weed and/or algal growth, and therefore, aerated wetland may initially require an increased frequency of maintenance visits for weed control and potential replanting of reeds.

\section{Conclusions and Outlook}

Over twenty years of experience with aerated treatment wetlands has provided significant insights into their application, design, performance, and operations and maintenance requirements. Aerated wetlands provide a higher level of treatment within a smaller footprint compared to traditional (non-aerated) HF and VF wetland systems and can provide treatment similar to or better than a municipal activated sludge wastewater treatment plant and, likewise, are economically attractive compared with other conventional wastewater treatment technologies such as submerged aerated filters and rotating biological contactors. Despite the immense progress in the understanding of aerated wetland technology, significant knowledge gaps and research questions still exist:

- Understanding biological clogging mechanisms in aerated treatment wetland systems. Does clogging occur differently in aerated wetlands than it does in non-aerated wetlands? At which organic cross-sectional loading does clogging in aerated wetlands become an issue? On which timescale does clogging occur in aerated wetlands? How does clogging influence air movement and oxygen transfer in aerated wetlands? Is clogging in aerated wetlands inevitable? Can clogging be managed (or even prevented) through targeted operations and maintenance activities?

- What are the seasonal dynamics and long-term removal of solid matter in aerated wetland systems? What is the composition of the suspended solid matter in aerated wetlands over time (e.g., organic versus mineral), within the saturated water column and as well as in the effluent? How can TSS removal in aerated wetlands be improved? For tertiary treatment aerated wetland systems, how can the systems be protected from upstream process failures causing sludge dumps and surface blinding?

- What is the response of aerated wetlands to organic overloads (e.g. influent organic loading that exceeds the calculated actual oxygen transfer rate of the system)? How long can organic overloading be sustained, and how quickly can aerated wetlands recover? Are there long-term repercussions to short-term organic overloads? Are there operational activities that can minimise the negative impacts of organic overloading?

- Sophisticated control of aeration based on the environmental conditions observed within aerated wetland beds. The literature is replete with studies that confirm increased TN removal can be achieved with the use of intermittent aeration; however, most studies use a timer to control the operation of the air pump. Control of the air pump based on the environmental conditions in the bed (e.g., $\mathrm{DO}, \mathrm{ORP}, \mathrm{NH}_{4}-\mathrm{N}$ ) has been shown to enable a more dynamic response and potentially provide an optimised use of aeration and a subsequent optimization in energy efficiency [51]. 
This can be achieved using variable speed drive air blowers, but the approach has yet to be optimized or widely implemented on full-scale systems.

- Pathogen removal processes in aerated wetland systems. Stefanakis et al. [75] report the first assessment of bacteriophages in aerated wetlands, and attribute the correlation of bacteria and bacteriophages in the effluent to the role of phages as bacterial predators. What are the primary mechanisms of pathogen removal in aerated wetlands? What is the potential of aerated wetland technology for disinfection? Can nanobubble technology be incorporated into aerated wetlands to improve pathogen removal efficacy?

- Improved understanding of micropollutant removal in aerated treatment wetlands. How is removal during start-up different from removal over multiple years of operation? Is removal temperature dependent, and how does removal differ with climate? Is the approach of using indicator chemicals, as first reported for removal of micropollutants in various treatment wetland designs by Kahl et al. [93], valid for similar individual compounds? Moreover, studies on micropollutant removal in treatment wetlands follow parent compounds only; very little research has been conducted on the fate and removal of transformation products. Removal of hormones and estrogens in aerated treatment wetlands has yet to be investigated. How does micropollutant correlate or compliment non-target screening methods and methods for assessing mixture effects.

- How well do aerated wetlands remove Antibiotic Resistant Bacteria (ARB) and Antibiotic Resistant Genes (ARB)? Conventional treatment wetland designs are effective at removing many antibiotic compounds [110], but the extent to which these compounds are removed in aerated wetlands is not known.

- Advancements in modelling of aerated wetland systems. First efforts on modelling of aerated wetlands have only been very recently reported. Models have been developed, but further work is needed to improve model descriptions of mass transfer through biofilm, microbial community dynamics, and behaviour of aerated treatment wetlands during dynamic events. Oxygen transfer is likely a function of the water quality, specifically for wastewater containing surfactants, oils, or petroleum-based compounds; parameters used for aerated wetland models will need to take this into account [88].

- Online monitoring instruments, flow meters, water quality probes, telemetry connections and web-based data management systems are all commercially available and improving in efficiency. Can aerated wetland design be improved to utilise these tools in order to monitor system performance and operation remotely, to flag any operational issues early on and to reduce unnecessary maintenance visits and associated OPEX?

- Aerated wetland economics and increasing use of whole life cost assessments in the technology selection process. How do conventional passive HF and VF constructed wetlands compare to aerated wetlands in terms of whole life costs, given the trade-off between footprint and energy consumption? How can we allocate ecosystem services monetary values in order to include them into whole life cost assessments? Can we expand whole life costs assessment across a broader range of technologies to establish economics when compared to aerated wetlands? Can we incorporate levels of reliability into whole life cost assessments as some technologies may be more robust than others, resulting in reduced down time and better performance?

- What is the potential of aerated wetlands for urban (waste)water treatment and reuse? Aerated wetlands have the capacity to provide high effluent quality in a compact system, making them particularly well-suited for application in urban environments where space is often limited. Dou et al. [111] suggest the use of aerated wetlands for tertiary and/or advanced treatment of wastewater, with the ultimate aim of urban reuse (e.g., closing urban water cycles), but research on this topic is lacking.

Most of these knowledge gaps can only be filled by prioritizing research studies on outdoor pilot- and full-scale aerated wetland systems treating actual wastewater under ambient conditions. 
Collaboration between groups working on applied research and fundamental research is needed. Long-term case studies are also needed. Frequent and regular long-term monitoring of outdoor systems treating actual wastewater is required in order to encompass the stochastic variability of influent and effluent water quality, as well as seasonal variations, in the performance of aerated treatment wetland systems.

Author Contributions: J.N. and C.M. contributed the conceptualization of the manuscript. J.N., C.M. and A.F. contributed to the preparation of this manuscript. All authors have read and agreed to the published version of the manuscript.

Funding: This research received no external funding.

Acknowledgments: This paper is an outcome of the 8th International Symposium on Wetland Pollutant Dynamics and Control (WETPOL), hosted by Aarhus University (Denmark), from 17-21 June 2019. The authors would like to thank the organisers of WETPOL2019, Hans Brix and Carlos Arias, and their entire team at Aarhus University, as well as the members of the Scientific and Steering committees, who made such a productive and engaging meeting possible. Scott Wallace is recognised for his immense and ongoing contributions to the field of aerated wetland implementation, research and development. JN would like to thank all the presenters who contributed to the WETPOL Special Session on aerated wetlands: Scott Wallace, Dion van Oirschot, Pascal Molle, and Clodagh Murphy, as well as the others who contributed to a second full session on the same topic: Jordi Morato, Chris Tanner, and Stéphane Troesch. In addition to the data provided by the Helmholtz Centre for Environmental Research-UFZ and ARM Ltd., we kindly acknowledge Carlos Arias (Aarhus University, Denmark), David Cooper (ARM Ltd), Dirk Esser (Sint, France), De Bruyn Joubert (Blue Crane Treatment Wetlands, South Africa), Rene Killian (Killian Water, Denmark), Fabio Masi (IRIDRA srl, Italy), Pascal Molle (INRAE, France), Dion van Oirschot (Rietland bvba, Belgium), Joelle Paing (Opure, France), Alexandros Stefanakis (BAUER Nimr LLC, Oman), Stéphane Troesch (Syntea, France) and Scott Wallace (Naturally Wallace Consulting LLC, USA), for contributing to the data presented in Figures 1 and 2.

Conflicts of Interest: The authors declare no conflict of interest.

\section{References}

1. Wallace, S.D. System for Removing Pollutants from Water. U.S. Patent 6,200,469 B1, 13 March 2001.

2. Wallace, S.D.; Nivala, J.A.; Meyers, T. Statistical analysis of treatment performance in aerated and non-aerated subsurface-flow constructed wetlands. In Wastewater Treatment, Plant Dynamics, and Management in Constructed and Natural Wetlands; Vymazal, J., Ed.; Springer: Dordrecht, The Netherlands, 2008; pp. 171-180.

3. Nivala, J.; Hoos, M.; Cross, C.; Wallace, S.; Parkin, G. Treatment of landfill leachate using an aerated, horizontal subsurface-flow constructed wetland. Sci. Total Environ. 2007, 380, 19-27. [CrossRef]

4. Nivala, J.; Wallace, S. Treatment of Landfill Leachate in Aerated Subsurface Flow Wetlands: Two Case Studies. In Water and Nutrient Management in Natural and Constructed Wetlands; Springer Science and Business Media LLC: Dordrecht, The Netherlands, 2010; pp. 121-131.

5. Wallace, S.; Kadlec, R.H. BTEX degradation in a cold-climate wetland system. Water Sci. Technol. 2005, 51, 165-171. [CrossRef] [PubMed]

6. Wallace, S.D. Treatment of Cheese-Processing Waste Using Subsurface Flow Wetlands; Nehring, K.W., Brauning, S.E., Eds.; Battelle Institute: Columbus, OH, USA, 2001.

7. Arias, C.; Oirschot, D.V.; Kilian, R.; Pascual, A.; Carvalho, P.; Lv, T.; Zhang, Y.; Brix, H.; Alvarez, J.A. Design and performance evaluation of a highly loaded aerated treatment wetland managing effluents from a food processing industry in Denmark. Water Pract. Technol. 2015, 10, 644-651. [CrossRef]

8. Higgins, J.P. The use of engineered wetlands to treat recalcitrant wastewaters. In Constructed Wetlands for Wastewater Treatment in Cold Climates; Mander, Ü., Jenssen, P., Eds.; WIT Press: Southampton, UK, 2003; pp. 137-160.

9. Higgins, J.P.; Liner, M.O.; Verkuijl, S.; Crolla, A.M. Engineered wetland pilot-scale treatability testing of ammonia- and cyanide-contaminated South American gold mine reclaim water. In Proceedings of the 31st Annual Meeting \& Conference of the Canadian Land Reclamation Association (CLRA) \& 9th Meeting of the International Affiliation of Land Reclamationists (IALR), Ottawa, ON, Canada, 20-23 August 2006.

10. Ong, S.-A.; Uchiyama, K.; Inadama, D.; Ishida, Y.; Yamagiwa, K. Treatment of azo dye Acid Orange 7 containing wastewater using up-flow constructed wetland with and without supplementary aeration. Bioresour. Technol. 2010, 101, 9049-9057. [CrossRef] [PubMed] 
11. Masi, F.; Fiore, S.; Bresciani, R.; Martinuzzi, N.; Wallace, S.; Van Oirschot, D.; Macor, F.; Rossini, T.; Fornaroli, R.; Mezzanotte, V. Lessons learnt from a pilot study on residual dye removal by an aerated treatment wetland. Sci. Total Environ. 2019, 648, 144-152. [CrossRef] [PubMed]

12. Masi, F.; Fiore, S.; Martinuzzi, N.; Wallace, S.D.; Van Oirschot, D.; Salazzari, P.; Meers, E.; Bresciani, R. Upflow anaerobic sludge blanket and aerated constructed wetlands for swine wastewater treatment: A pilot study. Water Sci. Technol. 2017, 76, 68-78. [CrossRef] [PubMed]

13. Murphy, C.; Wallace, S.; Knight, R.; Cooper, D.; Sellers, T. Treatment performance of an aerated constructed wetland treating glycol from de-icing operations at a UK airport. Ecol. Eng. 2015, 80, 117-124. [CrossRef]

14. Freeman, A.I.; Surridge, B.W.; Matthews, M.; Stewart, M.; Haygarth, P.M. New approaches to enhance pollutant removal in artificially aerated wastewater treatment systems. Sci. Total Environ. 2018, 627, 1182-1194. [CrossRef]

15. Troesch, S.; Petitjean, A.; Esser, D.; Wallerand, E.; Dobel, D. Treatment of airport runoff loaded with deicing fluids by an aerated constructed wetland and topsoil filtration-A pilot study at Paris-Charles de Gaulle Airport. In Proceedings of the 16th IWA International Conference on Wetland Systems for Water Pollution Control, València, Spain, 30 September-4 October 2018; Universitat Politècnica de València and IWA: València, Spain; pp. 158-161.

16. Wallace, S.; Parkin, G.; Cross, C. Cold climate wetlands: Design and performance. Water Sci. Technol. 2001, 44, 259-265. [CrossRef] [PubMed]

17. Wallace, S.D.; Nivala, J. Thermal Response of a Horizontal Subsurface Flow Wetland in A Cold Temperate Climate. International Water Association's Specialist Group on Use of Macrophytes in Water Pollution Control No. 29. February 2005, pp. 23-30. Available online: http://naturallywallace.com/docs/77_Technical\% 20Paper\%20-\%20IWA\%20Newsletter\%20Thermal.pdf (accessed on 20 April 2020).

18. Nivala, J. Effect of Design on Treatment Performance, Plant Nutrition and Clogging in Subsurface Flow Treatment Wetlands. Ph.D. Thesis, Department of Bioscience, Aarhus University, Aarhus, Denmark, 2012.

19. Murphy, C.; Wallace, S.; Cooper, D. Treatment performance of two aerated saturated vertical flow constructed wetlands treating settled sewage. In Proceedings of the 13th IWA Specialist Group Conference on Wetland Systems for Water Pollution Control, Perth, Australia, 25-29 November 2012; Mathew, K., Dallas, S., Eds.; Murdoch University, AWA and IWA: Perth, Australia.

20. Butterworth, E.; Dotro, G.; Jones, M.; Richards, A.; Onunkwo, P.; Narroway, Y.; Jefferson, B. Effect of artificial aeration on tertiary nitrification in a full-scale subsurface horizontal flow constructed wetland. Ecol. Eng. 2013, 54, 236-244. [CrossRef]

21. Nivala, J.; Murphy, C.; Troesch, S.; Wallace, S.; Esser, D. Intensified and modified wetland designs. Sustain. Sanit. Pract. J. 2014, 18, 15-20.

22. Van Oirschot, D.; Hawes, P.; Wallace, S.D. Aerated wetlands treating high flow/low concentration waste waters. In Proceedings of the 8th International Symposium on Wetland Pollutant Dynamics and Control (WETPOL), Aarhus, Denmark, 17-21 June 2019; Aarhus University: Aarhus, Denmark; p. 64.

23. Metcalf and Eddy Inc. Wastewater Engineering: Treatment, Disposal, and Reuse, 4th ed.; McGraw-Hill: New York, NY, USA, 2003.

24. ASCE. Measurement of Oxygen Transfer in Clean Water; American Society of Chemical Engineers: Reston, VA, USA, 2007.

25. Wallace, S.D.; Liner, M.O.; Redmon, D.; Hildebrand, M. Oxygen transfer efficiency in aerated subsurface flow wetlands. In Proceedings of the 2nd International Symposium on Wetland Pollutant Dynamics and Control (WETPOL), University of Tartu, Tartu, Estonia, 16-20 September 2007.

26. Nivala, J.; Headley, T.; Wallace, S.; Bernhard, K.; Brix, H.; van Afferden, M.; Müller, R.A. Comparative analysis of constructed wetlands: The design and construction of the ecotechnology research facility in Langenreichenbach, Germany. Ecol. Eng. 2013, 61, 527-543. [CrossRef]

27. Wallace, S.D.; van Oirschot, D.; Stefanakis, A.I. Chapter 5.7: Aerated wetlands. In Wetland Technology: Practical Information on the Design and Application of Treatment Wetlands; Langergraber, G., Dotro, G., Nivala, J., Rizzo, A., Stein, O., Eds.; IWA Publishing: London, UK, 2019; pp. 105-107. Available online: https: //iwaponline.com/ebooks/book-pdf/644599/wio9781789060171 (accessed on 20 April 2020).

28. Butterworth, E. The Use of Artificial Aeration in Horizontal Sub-Surface Flow Constructed Wetlands for Tertiary Nitrification. Ph.D. Thesis, Cranfield University, School of Applied Sciences, Cranfield, UK, March 2014. 
29. DWA. Standard DWA-A 262E: Principles for Dimensioning, Construction And Operation of Wastewater Treatment Plants with Planted And Unplanted Filters for Treatment of Domestic And Municipal Wastewater; German Association for Water, Wastewater and Waste (DWA): Hennef, Germany, 2017.

30. Nivala, J.; van Afferden, M.; Hasselbach, R.; Langergraber, G.; Molle, P.; Rustige, H.; Nowak, J. The new German standard on constructed wetland systems for treatment of domestic and municipal wastewater. Water Sci. Technol. 2018, 78, 2414-2426. [CrossRef] [PubMed]

31. Wallace, S.D.; Knight, R.L. Small-Scale Constructed Wetland Treatment Systems: Feasibility, Design Criteria, and OEM Requirements; Water Environment Research Foundation (WERF): Alexandria, VA, USA, 2006.

32. Wallace, S.D. Reducing wetland area requirements by using intensification strategies. In Proceedings of the 14th IWA Specialist Group Conference on Wetland Systems for Water Pollution Control, Shanghai, China, 4-8 October 2014; Zhou, Q., Zhai, J., Eds.; Tonji University, Chongqing University, and IWA: Shanghai, China; pp. 54-64.

33. Grady, C.P.L.J.; Lim, H.C.; Daigger, G.T. Biological Wastewater Treatment; Marcel Dekker, Inc.: New York, NY, USA, 1999.

34. Wallace, S.D.; Liner, M.O. Nutrient limitations in industrial treatment wetlands. In Proceedings of the 12th IWA Specialist Group Conference on Wetland Systems for Water Pollution Control, Venice, Italy, 4-8 October 2010; IWA: Venice, Italy; pp. 1071-1074.

35. Wallace, S.D.; Liner, M.O. Design and Performance of the Wetland Treatment System at the Buffalo Niagara International Airport. IWA Specialist Group on the Use of Aquatic Macrophytes for Water Pollution Control No. 38. June 2011. Available online: https://www.yumpu.com/en/document/read/7975240/specialist-groupon-use-of-macrophytes-in-water-pollution-iwa (accessed on 20 April 2020).

36. Nivala, J.; Aubron, T.; Boog, J.; Prigent, S.; van Afferden, M.; Müller, R.A. Treatment wetlands in arid climates: New pilot-scale results and experience with full-scale systems in Jordan. In Proceedings of the 8th International Symposium on Wetland Pollutant Dynamics and Control (WETPOL), Aarhus, Denmark, 17-21 June 2019; Aarhus University: Aarhus, Denmark; p. 113.

37. Stefanakis, A.I. The role of constructed wetlands as green infrastructure for sustainable urban water management. Sustainability 2019, 11, 6981. [CrossRef]

38. Park, J.; Sukias, J.P.; Tanner, C.C. Floating treatment wetlands supplemented with aeration and biofilm attachment surfaces for efficient domestic wastewater treatment. Ecol. Eng. 2019, 139, 105582. [CrossRef]

39. Troesch, S.; Esser, D.; Wallace, S.D.; van Oirschot, D. Wastewater Puriifcation Device and Utilizations. U.S. Patent 10,526,222 B2, 7 January 2020.

40. Molle, P.; Prost-Boucle, S.; Troesch, S.; Morvannou, A. Forced aeration and TN removal in single stage vertical flow treatment wetlands fed by raw wastewater. In Proceedings of the 8th International Symposium on Wetland Pollutant Dynamics and Control (WETPOL), Aarhus, Denmark, 17-21 June 2019; Aarhus University: Aarhus, Denmark; p. 65.

41. Serdobbel, V.; Paing, J.; Chazarenc, F.; Molle, P. Forced aeration vertical flow treatment wetland fed by raw wastewater: Design and aeration mode to enhance TN removal. In Proceedings of the 8th International Symposium on Wetland Pollutant Dynamics and Control (WETPOL), Aarhus, Denmark, 17-21 June 2019; Aarhus University: Aarhus, Denmark; p. 171.

42. Mozaffari, M.H.; Shafiepour, E.; Rakhshandehroo, G.S.A.M.; Wallace, S.D. Oil Refinery Waste Water Treatment Using Aerated Racetrack Wetland System. Iran Invention Registration Number 97287, 21 June 2018.

43. Zhong, F.; Wu, J.; Dai, Y.; Xiang, D.; Cheng, S.; Ji, H. Performance evaluation of wastewater treatment using horizontal subsurface flow constructed wetlands optimized by micro-aeration and substrate selection. Water Sci. Technol. 2015, 71, 1317-1324. [CrossRef]

44. Austin, D.; Vazquez-Burney, R.; Dyke, G.; King, T. Nitrification and total nitrogen removal in a super-oxygenated wetland. Sci. Total Environ. 2019, 652, 307-313. [CrossRef]

45. Matthys, A.; Parkin, G.F.; Wallace, S.D. A comparison of constructed wetlands used to treat domestic wastes: Conventional, drawdown, and aerated systems. In Proceedings of the 7th IWA Specialist Group Conference on Wetland Systems for Water Pollution Control, Lake Buena Vista, FL, USA, 11-16 November 2000; University of Florida and IWA: Lake Buena Vista, FL, USA.

46. Wallace, S.D. Design and performance of cold climate wetland treatment systems. In Proceedings of the 2000 NOWRA Annual Meeting, Grand Rapids, MI, USA, 31 October-3 November 2000; National Onsite Wastewater Recycling Association: Grand Rapids, MI, USA; pp. 230-239. 
47. Wallace, S.D. Onsite remediation of petroleum contact wastes using subsurface flow wetlands. In Proceedings of the Wetlands and Remediation: The Second International Conference, Burlington, VT, USA, 5-6 September 2001; Battelle Institute: Columbus, OH, USA.

48. Lockhart, A. A Comparison of Constructed Wetlands Used to Treat Domestic Wastes: Conventional, Drawdown, and Aerated Systems. Master's Thesis, Department of Civil and Environmental Engineering, University of Iowa, Iowa City, IA, USA, 1999.

49. Pan, J.; Zhang, H.; Li, W.; Ke, F. Full-scale experiment on domestic wastewater treatment by combining artificial aeration vertical- and horizontal-flow constructed wetlands system. Water Air Soil Pollut. 2012, 223, 5673-5683. [CrossRef]

50. Redmond, E.D.; Just, C.L.; Parkin, G.F. Nitrogen removal from wastewater by an aerated subsurface-flow constructed wetland in cold climates. Water Environ. Res. 2014, 86, 305-313. [CrossRef] [PubMed]

51. Uggetti, E.; Hughes-Riley, T.; Morris, R.; Newton, M.; Trabi, C.; Hawes, P.; Puigagut, J.; Garcia, J. Intermittent aeration to improve wastewater treatment efficiency in pilot-scale constructed wetland. Sci. Total Environ. 2016, 559, 212-217. [CrossRef]

52. Tang, X.; Huang, S.; Scholz, M.; Li, J. Nutrient removal in pilot-scale constructed wetlands treating eutrophic river water: Assessment of plants, intermittent artificial aeration and polyhedron hollow polypropylene balls. Water Air Soil Pollut. 2008, 197, 61-73. [CrossRef]

53. Zhang, L.-Y.; Zhang, L.; Liu, Y.; Shen, Y.-W.; Liu, H.; Xiong, Y. Effect of limited artificial aeration on constructed wetland treatment of domestic wastewater. Desalination 2010, 250, 915-920. [CrossRef]

54. Hu, Y.; Zhao, Y.; Zhao, X.; Kumar, J.L.G. High rate nitrogen removal in an alum sludge-based intermittent aeration constructed wetland. Environ. Sci. Technol. 2012, 46, 4583-4590. [CrossRef]

55. Fan, J.; Wang, W.; Zhang, B.; Guo, Y.; Ngo, H.-H.; Guo, W.; Zhang, J.; Wu, H. Nitrogen removal in intermittently aerated vertical flow constructed wetlands: Impact of influent COD/N ratios. Bioresour. Technol. 2013, 143, 461-466. [CrossRef] [PubMed]

56. Fan, J.; Zhang, B.; Zhang, J.; Ngo, H.-H.; Guo, W.; Liu, F.; Guo, Y.; Wu, H. Intermittent aeration strategy to enhance organics and nitrogen removal in subsurface flow constructed wetlands. Bioresour. Technol. 2013, 141, 117-122. [CrossRef] [PubMed]

57. Foladori, P.; Ruaben, J.; Ortigara, A.R. Recirculation or artificial aeration in vertical flow constructed wetlands: A comparative study for treating high load wastewater. Bioresour. Technol. 2013, 149, 398-405. [CrossRef]

58. Liu, L.; Zhao, X.; Zhao, N.; Shen, Z.; Wang, M.; Guo, Y.; Xu, Y. Effect of aeration modes and influent COD/N ratios on the nitrogen removal performance of vertical flow constructed wetland. Ecol. Eng. 2013, 57, 10-16. [CrossRef]

59. Boog, J.; Nivala, J.; Aubron, T.; Wallace, S.; van Afferden, M.; Müller, R.A. Hydraulic characterization and optimization of total nitrogen removal in an aerated vertical subsurface flow treatment wetland. Bioresour. Technol. 2014, 162, 166-174. [CrossRef] [PubMed]

60. Wu, H.; Fan, J.; Zhang, J.; Ngo, H.-H.; Guo, W.; Hu, Z.; Liang, S. Decentralized domestic wastewater treatment using intermittently aerated vertical flow constructed wetlands: Impact of influent strengths. Bioresour. Technol. 2015, 176, 163-168. [CrossRef] [PubMed]

61. Zapater-Pereyra, M.; Ilyas, H.; Lavrnic, S.; Van Bruggen, J.; Lens, P.N. Evaluation of the performance and space requirement by three different hybrid constructed wetlands in a stack arrangement. Ecol. Eng. 2015, 82, 290-300. [CrossRef]

62. Wu, H.; Fan, J.; Zhang, J.; Ngo, H.-H.; Guo, W.; Liang, S.; Lv, J.; Lu, S.; Wu, W.; Wu, S. Intensified organics and nitrogen removal in the intermittent-aerated constructed wetland using a novel sludge-ceramsite as substrate. Bioresour. Technol. 2016, 210, 101-107. [CrossRef]

63. Chen, X.; Zhu, H.; Xu, Y.; Shutes, B.; Yan, B.; Zhou, Q. Effect of aeration modes and COD/N ratios on organic matter and nitrogen removal in horizontal subsurface flow constructed wetland mesocosms. Water 2018, 10, 1530. [CrossRef]

64. Hou, J.; Wang, X.; Wang, J.; Xia, L.; Zhang, Y.; Li, D.; Ma, X. Pathway governing nitrogen removal in artificially aerated constructed wetlands: Impact of aeration mode and influent chemical oxygen demand to nitrogen ratios. Bioresour. Technol. 2018, 257, 137-146. [CrossRef] [PubMed]

65. Zhou, X.; Jia, L.; Liang, C.; Feng, L.; Wang, R.; Wu, H. Simultaneous enhancement of nitrogen removal and nitrous oxide reduction by a saturated biochar-based intermittent aeration vertical flow constructed wetland: Effects of influent strength. Chem. Eng. J. 2018, 334, 1842-1850. [CrossRef] 
66. Boog, J.; Nivala, J.; Aubron, T.; Wallace, S.; Sullivan, C.; van Afferden, M.; Müller, R.A. Treatment wetland aeration without electricity? Lessons learned from the first experiment using a wind-driven air pump. Water 2016, 8, 502. [CrossRef]

67. Ilyas, H.; Masih, I. The performance of the intensified constructed wetlands for organic matter and nitrogen removal: A review. J. Environ. Manag. 2017, 198, 372-383. [CrossRef]

68. Chazarenc, F.; Gagnon, V.; Comeau, Y.; Brisson, J. Effect of plant and artificial aeration on solids accumulation and biological activities in constructed wetlands. Ecol. Eng. 2009, 35, 1005-1010. [CrossRef]

69. Nivala, J.; Kahl, S.; Boog, J.; van Afferden, M.; Reemtsma, T.; Müller, R.A. Dynamics of emerging organic contaminant removal in conventional and intensified subsurface flow treatment wetlands. Sci. Total Environ. 2019, 649, 1144-1156. [CrossRef]

70. Ilyas, H.; Masih, I. The effects of different aeration strategies on the performance of constructed wetlands for phosphorus removal. Environ. Sci. Pollut. Res. 2018, 25, 5318-5335. [CrossRef]

71. Headley, T.; Nivala, J.; Kassa, K.; Olsson, L.; Wallace, S.; Brix, H.; van Afferden, M.; Müller, R. Escherichia coli removal and internal dynamics in subsurface flow ecotechnologies: Effects of design and plants. Ecol. Eng. 2013, 61, 564-574. [CrossRef]

72. Nivala, J.; Boog, J.; Headley, T.; Aubron, T.; Wallace, S.; Brix, H.; Mothes, S.; van Afferden, M.; Müller, R.A. Side-by-side comparison of 15 pilot-scale conventional and intensified subsurface flow wetlands for treatment of domestic wastewater. Sci. Total Environ. 2019, 658, 1500-1513. [CrossRef]

73. Boog, J. Effect of the Aeration Scheme on the Treatment Performance of Intensified Treatment Wetland Systems. Master's Thesis, TU Bergakademie Freiberg, Freiberg, Germany, 2013.

74. Button, M.; Nivala, J.; Weber, K.P.; Aubron, T.; Müller, R.A. Microbial community metabolic function in subsurface flow constructed wetlands of different designs. Ecol. Eng. 2015, 80, 162-171. [CrossRef]

75. Stefanakis, A.I.; Bardiau, M.; Trajano, D.; Couceiro, F.; Williams, J.; Taylor, H. Presence of bacteria and bacteriophages in full-scale trickling filters and an aerated constructed wetland. Sci. Total Environ. 2018, 659, 1135-1145. [CrossRef]

76. World Health Organization. Guidelines for the Safe Reuse of Wastewater, Excreta and Greywater. Volume II: Wastewater Use in Agriculture; WHO: Geneva, Switzerland, 2006.

77. Ouellet-Plamondon, C.; Chazarenc, F.; Comeau, Y.; Brisson, J. Artificial aeration to increase pollutant removal efficiency of constructed wetlands in cold climate. Ecol. Eng. 2006, 27, 258-264. [CrossRef]

78. Ong, S.-A.; Uchiyama, K.; Inadama, D.; Ishida, Y.; Yamagiwa, K. Performance evaluation of laboratory scale up-flow constructed wetlands with different designs and emergent plants. Bioresour. Technol. 2010, 101, 7239-7244. [CrossRef]

79. Wang, X.; Tian, Y.; Zhao, X.; Peng, S.; Wu, Q.; Yan, L. Effects of aeration position on organics, nitrogen and phosphorus removal in combined oxidation pond-constructed wetland systems. Bioresour. Technol. 2015, 198,7-15. [CrossRef]

80. Zhong, F.; Wu, J.; Dai, Y.; Yang, L.; Zhang, Z.; Cheng, S.; Zhang, Q. Bacterial community analysis by PCR-DGGE and 454-pyrosequencing of horizontal subsurface flow constructed wetlands with front aeration. Appl. Microbiol. Biotechnol. 2014, 99, 1499-1512. [CrossRef]

81. Aubron, T.; Kahl, S.; Nivala, J.; Boog, J.; Möder, M.; van Afferden, M.; Reemtsma, T.; Müller, R.A. Two Years Performance of a Horizontal Subsurface Flow Wetland with Zoned Aeration; International Water Association (IWA): Gdansk, Poland, 2016; p. 62.

82. Freeman, A.I. Treatment of De-icer Contaminated Storm Runoff from Airport Catchments within Artifically Aerated Wetlands. Ph.D. Thesis, Lancaster University, Centre for Global Eco-Innovation, Lancaster, UK, 19 December 2016.

83. Murphy, C.; Rajabzadeh, A.R.; Weber, K.P.; Nivala, J.; Wallace, S.D.; Cooper, D.J. Nitrification cessation and recovery in an aerated saturated vertical subsurface flow treatment wetland: Field studies and microscale biofilm modeling. Bioresour. Technol. 2016, 209, 125-132. [CrossRef] [PubMed]

84. Boog, J.; Nivala, J.; Aubron, T.; Mothes, S.; van Afferden, M.; Müller, R.A. Resilience of carbon and nitrogen removal due to aeration interruption in aerated treatment wetlands. Sci. Total Environ. 2018, 621, 960-969. [CrossRef] [PubMed]

85. Boog, J.; Kalbacher, T.; Nivala, J.; Forquet, N.; van Afferden, M.; Müller, R.A. Modeling the relationship of aeration, oxygen transfer and treatment performance in aerated horizontal flow treatment wetlands. Water Res. 2019, 157, 321-334. [CrossRef] [PubMed] 
86. Boog, J.; Kalbacher, T.; Nivala, J.; van Afferden, M.; Müller, R.A.; Manfred, V.A. Modeling dynamics of organic carbon and nitrogen removal during aeration interruption in aerated horizontal flow treatment wetlands. Water Sci. Technol. 2019, 80, 597-606. [CrossRef] [PubMed]

87. John, Y.; Langergraber, G.; Adyel, T.M.; David, V.E. Aeration intensity simulation in a saturated vertical up-flow constructed wetland. Sci. Total Environ. 2020, 708, 134793. [CrossRef] [PubMed]

88. Boog, J.; Nivala, J.; Kalbacher, T.; van Afferden, M.; Müller, R.A. Do wastewater pollutants impact oxygen transfer in aerated horizontal flow wetlands? Chem. Eng. J. 2020, 383, 123173. [CrossRef]

89. Matamoros, V.; Bayona, J.M. Elimimation of pharmaceuticals and personal care products in subsurface flow constructed wetlands. Environ. Sci. Technol. 2006, 40, 5811-5816. [CrossRef]

90. Avila, C.; Nivala, J.; Olsson, L.; Kassa, K.; Headley, T.; Mueller, R.A.; Bayona, J.M.; Garcia, J. Emerging organic contaminants in vertical subsurface flow constructed wetlands: Influence of media size, loading frequency and use of active aeration. Sci. Total Environ. 2014, 494, 211-217. [CrossRef]

91. Ilyas, H.; van Hullebusch, E.D. Role of design and operational factors in the removal of pharmaceuticals by constructed wetlands. Water 2019, 11, 2356. [CrossRef]

92. Weber, K.P.; Nivala, J. Chapter 4.9: Treatment of micropollutants. In Wetland Technology: Practical Information on the Design and Application of Treatment Wetlands; Langergraber, G., Dotro, G., Nivala, J., Rizzo, A., Stein, O., Eds.; IWA Publishing: London, UK, 2019; pp. 44-47. Available online: https://iwaponline.com/ebooks/bookpdf/644599/wio9781789060171 (accessed on 20 April 2020).

93. Kahl, S.; Nivala, J.; van Afferden, M.; Müller, R.A.; Reemtsma, T. Effect of design and operational conditions on the performance of subsurface flow treatment wetlands: Emerging organic contaminants as indicators. Water Res. 2017, 125, 490-500. [CrossRef] [PubMed]

94. Auvinen, H.; Havran, I.; Hubau, L.; Vanseveren, L.; Gebhardt, W.; Linnemann, V.; Van Oirschot, D.; Du Laing, G.; Rousseau, D. Removal of pharmaceuticals by a pilot aerated sub-surface flow constructed wetland treating municipal and hospital wastewater. Ecol. Eng. 2017, 100, 157-164. [CrossRef]

95. Zhang, L.; Lv, T.; Zhang, Y.; Stein, O.R.; Arias, C.A.; Brix, H.; Carvalho, P.N. Effects of constructed wetland design on ibuprofen removal-A mesocosm scale study. Sci. Total Environ. 2017, 609, 38-45. [CrossRef]

96. Nivala, J.; Neale, P.A.; Haasis, T.; Kahl, S.; König, M.; Müller, R.A.; Reemtsma, T.; Schlichting, R.; Escher, B.I. Application of cell-based bioassays to evaluate treatment efficacy of conventional and intensified treatment wetlands. Environ. Sci. Water Res. Technol. 2018, 4, 206-217. [CrossRef]

97. Nivala, J.; Abdallat, G.; Aubron, T.; Al-Zreiqat, I.; Abbassi, B.; Wu, G.-M.; van Afferden, M.; Müller, R.A. Vertical flow constructed wetlands for decentralized wastewater treatment in Jordan: Optimization of total nitrogen removal. Sci. Total Environ. 2019, 671, 495-504. [CrossRef] [PubMed]

98. Austin, D.; Nivala, J. Energy requirements for nitrification and biological nitrogen removal in engineered wetlands. Ecol. Eng. 2009, 35, 184-192. [CrossRef]

99. Freeman, A.I.; Widdowson, S.; Murphy, C.; Cooper, D.J. Economic assessment of aerated constructed treatment wetlands using whole life costing. Water Sci. Technol. 2019, 80, 75-85. [CrossRef]

100. Brix, H.; Johansen, N.H. Guidelines for the Establishment of Reed Bed Systems up to 30 PE; Miljøministeriet: Århus, Denmark, 2004. (In Danish)

101. Labella, A.; Caniani, D.; Hughes-Riley, T.; Morris, R.H.; Newton, M.I.; Hawes, P.; Puigagut, J.; Garcia, J.; Uggetti, E. Assessing the economic suitability of aeration and the influence of bed heating on constructed wetlands treatment efficiency and life-span. Ecol. Eng. 2015, 83, 184-190. [CrossRef]

102. United Nations World Water Assessment Programme. The United Nations Development Report 2018: Nature-Based Solutions for Water; UNESCO: Paris, France, 2018.

103. Collingnon, D. Insight into Oxygen Transfer in IFAS Processes. Master's Thesis, Cranfield University, Cranfield, UK, 2006.

104. Van Oirschot, D.; Wallace, S.D. Treatment of waste water from a fruit processing industry with an aerated wetland. In Proceedings of the 16th IWA International Conference on Wetland Systems for Water Pollution Control, València, Spain, 30 September-4 October 2018; Universitat Politècnica de València and IWA: València, Spain; pp. 156-157.

105. Kadlec, R.H.; Wallace, S.D. Treatment Wetlands, 2nd ed.; CRC Press: Boca Raton, FL, USA, 2009.

106. Nivala, J.; Knowles, P.; Dotro, G.; Garcia, J.; Wallace, S. Clogging in subsurface-flow treatment wetlands: Measurement, modeling and management. Water Res. 2012, 46, 1625-1640. [CrossRef] 
107. Butterworth, E.; Richards, A.; Jones, M.; Brix, H.; Dotro, G.; Jefferson, B. Impact of aeration on macrophyte establishment in sub-surface constructed wetlands used for tertiary treatment of sewage. Ecol. Eng. 2016, 91, 65-73. [CrossRef]

108. Weedon, C.M. Yellow phragmites: Significance, cause and remedies. Sustain. Sanit. Pract. J. 2014, 18, 37-42.

109. Ren, L.; Eller, F.; Lambertini, C.; Guo, W.; Sorrell, B.; Brix, H. Minimum Fe requirement and toxic tissue concentration of Fe in Phragmites australis: A tool for alleviating Fe-deficiency in constructed wetlands. Ecol. Eng. 2018, 118, 152-160. [CrossRef]

110. García, J.; García-Galán, M.J.; Day, J.W.; Boopathy, R.; White, J.R.; Wallace, S.D.; Hunter, R.G. A review of emerging organic contaminants (EOCs), antibiotic resistant bacteria (ARB), and antibiotic resistance genes (ARGs) in the environment: Increasing removal with wetlands and reducing environmental impacts. Bioresour. Technol. 2020, 307. [CrossRef] [PubMed]

111. Dou, T.; Troesch, S.; Petitjean, A.; Gábor, P.T.; Esser, D. Wastewater and rainwater management in urban areas: A role for constructed wetlands. Procedia Environ. Sci. 2017, 37, 535-541. [CrossRef]

(C) 2020 by the authors. Licensee MDPI, Basel, Switzerland. This article is an open access article distributed under the terms and conditions of the Creative Commons Attribution (CC BY) license (http://creativecommons.org/licenses/by/4.0/). 